\title{
New ceramic microfiltration membranes from Tunisian natural materials: Application for the cuttlefish effluents treatment
}

\author{
Sabeur Khemakhem ${ }^{1}$, André Larbot ${ }^{2}$, Raja Ben Amar ${ }^{1}$ \\ 1-Université de Sfax, Laboratoire des Sciences de Matériaux et Environnement, Faculté des \\ Sciences de Sfax, Route de Soukra Km 4, 3038, Sfax, Tunisie. \\ 2-Université de Montpellier II, Institut Européen des Membranes, UMR 5635-CNRS, \\ ENSCM, UMII, 1919 Route de Mende 34293 Montpellier Cedex5, France.
}

\section{Introduction}

Interest in separation by the use of membranes has rapidly increased during the last 10 - 15 years. The membrane technologies are utilized in various fields: chemistry, food, biotechnology and recently waste water treatment (Cham \& Brownstein, 1991). For economic consideration, a great deal of research has been devoted to the development of new type of inorganic membranes, which have displayed improved resistance to heat, chemicals and corrosion. Rapid development and innovation have already been realised in this area (Uhlhorn et al., 1987; Zespalis et al., 1989; Cot, 1998). Clay minerals have well-known structural adsorption, rheological and thermal properties (Jones \& Galan, 1988; Pérez, 1994). Research on clay as a membrane material has concentrated mainly on pillared clays (Mishra \& Parida, 1997; Cool et al., 1997). Studies of membranes prepared entirely from clay have just started (Messaoudi et al., 1995 ; Ishiguro et al., 1995; Le Van Mao et al., 1999; Rakib et al., 2000). The industry of conservation of sea products is very important in Tunisia. It produces a great amount of waste water which is generally rejected in the littoral and then is responsible for an enormous pollution, by supporting the eutrophication phenomenon (Dégrement, 1978). Before freezing, the cuttlefish must be washed to eliminate black colour caused by the ink contained in the animal bag, resulting in highly coloured wastewater (Abdelmouleh, 1997).

In this study, we investigate the development of ceramic membranes based on Tunisian natural materials which are in abundance and need lower firing temperature in comparison with metal oxide materials. The prepared microfiltration membranes were used for the treatment and the decoloration of cuttlefish effluent.

New microfiltration membranes from Tunisian natural materials are obtained using ceramic method. Paste from Tunisian silty marls refereed $\left(\mathrm{M}_{11}\right)$ is extruded to elaborate a porous tubular configuration used as supports. The support heated at $1190^{\circ} \mathrm{C}$, shows an average pore diameters and porosity of about $9.2 \mu \mathrm{m}$ and $49 \%$ respectively. The properties in term of mechanical and corrosion resistances are very interesting. The elaboration of the layer based on Tunisian clay refereed $\left(\mathrm{JM}_{18}\right)$ is performed by slip casting method. The heating treatment at $900^{\circ} \mathrm{C}$ leads to an 
average pore size of $0.18 \mu \mathrm{m}$. The water permeability determined of this membrane is $8671 . \mathrm{h}^{-1} . \mathrm{m}^{-}$ 2.bar-1. This membrane can be used for crossflow microfiltration. The application to the cuttlefish effluent clarification shows an important decrease of turbidity (inferior to 1 NTU) and chemical organic demand (COD) values (retention rate of about 65\%). So, it seems that the prepared membrane is suitable for such waste water treatment.

\section{Experimental results}

Microfiltration ceramic membranes were developed and prepared in the laboratory. They consist of a clay skin layer prepared by slip-casting method (Guizard t al., 1997) deposited on a silty marls support.

\subsection{Support shaping and characterisation:}

For this study, the supports were prepared from Tunisian silty marls $\left(\mathrm{M}_{11}\right)$. The chemical composition of these materials is shown in Table 1.

\begin{tabular}{ccccccccc}
\hline Elements (\%) & $\mathrm{SiO}_{2}$ & $\mathrm{Al}_{2} \mathrm{O}_{3}$ & $\mathrm{Fe}_{2} \mathrm{O}_{3}$ & $\mathrm{CaO}$ & $\mathrm{MgO}$ & $\mathrm{Na}_{2} \mathrm{O}$ & $\mathrm{K}_{2} \mathrm{O}$ & $\mathrm{TiO}_{2}$ \\
\hline $\mathrm{M}_{11}$ & 31.61 & 10.38 & 6.53 & 24.17 & 19.92 & 2.21 & 3.43 & 1.55 \\
\hline
\end{tabular}

Table 1. Composition of silty marls $\left(\mathrm{M}_{11}\right)$.

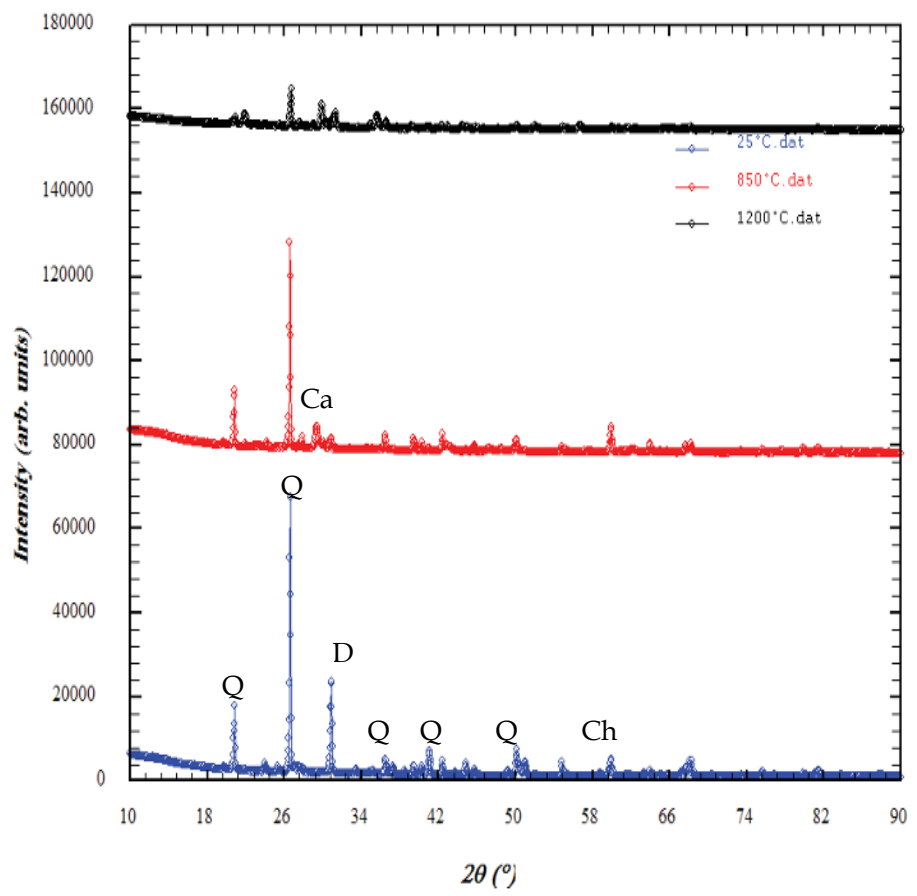

Fig. 1. X-ray diffractograms of the silty marls sample at different temperatures $(\mathrm{Q}=$ quartz, $\mathrm{Ca}=$ calcite, $\mathrm{Ch}=$ chlorite, $\mathrm{D}=$ dolomite). 
The chemical analysis reveals that this kind of silty marls is essentially formed with a great amount of silica and calcium oxide. Figure 1 presents the XRD patterns of raw silty marls, it shows that Quartz $(\mathrm{Q})$ is the main crystalline mineral present in this powder.

The particle size analysis of the powder after crushing for $2 \mathrm{~h}$ with the assistance of a planetary crusher at a rate of 250 revolutions / $\mathrm{min}$ and calibrated with $100 \mu \mathrm{m}$ was determined using a Particle Sizing Systems (Inc. Santa Barbara, Calif., USA Model 770 AccuSizer). The particle diameters range varied from 0.5 to $54 \mu \mathrm{m}$. (Fig 2).

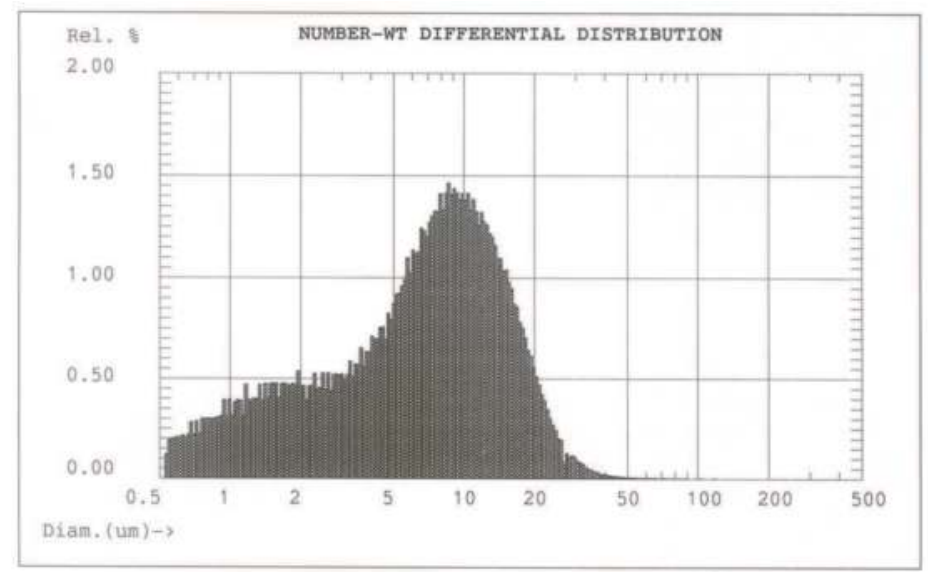

Fig. 2. Silty marls $\left(\mathrm{M}_{11}\right)$ particle-size distribution.

Plastic pastes are prepared from ceramic powder of silty marls mixed with organic additives:

- $\quad 4 \% \mathrm{w} / \mathrm{w}$ of Amijel: pregelated starch, as plasticizer (Cplus 12072, cerestar).

- $\quad 4 \% \mathrm{w} / \mathrm{w}$ of Methocel: cellulose derivative, as binder (The dow chemical company).

- $\quad 8 \% \mathrm{w} / \mathrm{w}$ of starch of corn as porosity agent (RG 03408, Cerestar).

- $\quad 25 \% \mathrm{w} / \mathrm{w}$ of water.

The rheological properties must be studied to obtain a paste allowing shaping by extrusion process (Khemakhem et al., 2006). Figure 3 shows the different configurations of tubes extruded in our laboratory (Two monochannel of different diameter and one multichannel tube).

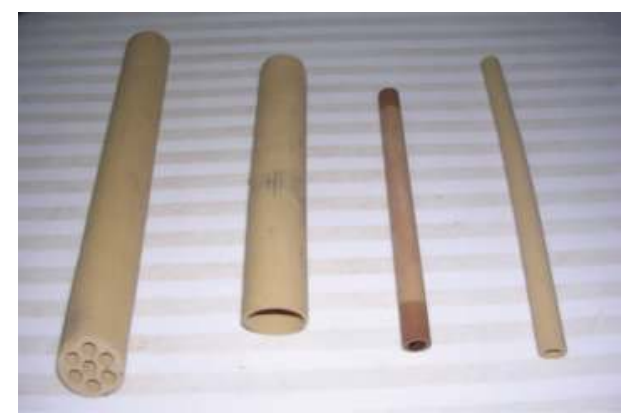

Fig. 3. A photograph of variety of configurations of porous ceramic supports. 
Thermogravimetric analysis (TGA) and differential scanning calorimetry (DSC) were performed with simultaneous DSC-TGA 2960 TA instrument. The sample was heated at room temperature to $1250^{\circ} \mathrm{C}$ at a rate of $5^{\circ} \mathrm{C} / \mathrm{min}$ under static atmospheric conditions. Two endothermic peaks were detected (Fig. 4). First peak appears at $51.38^{\circ} \mathrm{C}$, due to a weight loss of $1.81 \%$ of the initial weight. It corresponds to the departure of water (moisture or adsorption) due to attraction on the surface of the sample and zeolitic water inserted between the layers or in the cavities of the crystalline structure. Second peak which maximum appears toward $749,87^{\circ} \mathrm{C}$ corresponds to the dehydroxylation.

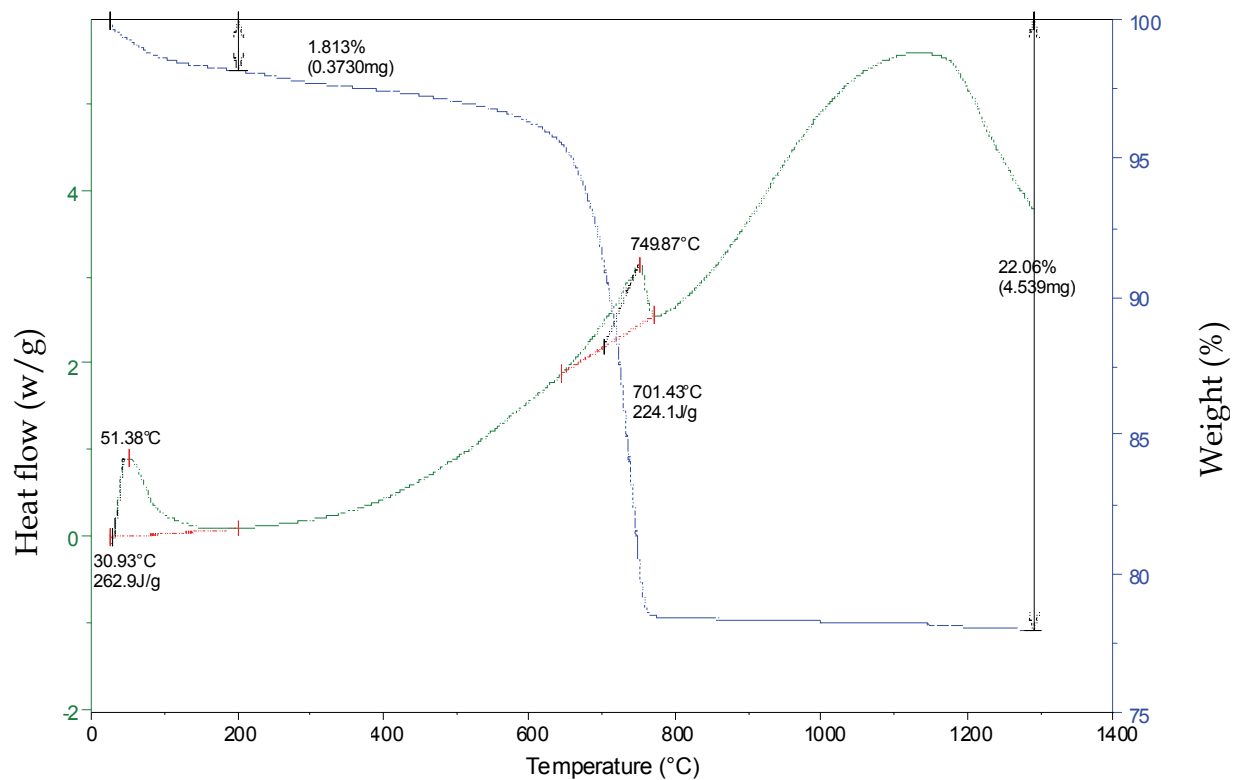

Fig. 4. Thermal analysis curve: DSC and TGA for silty marls powder.

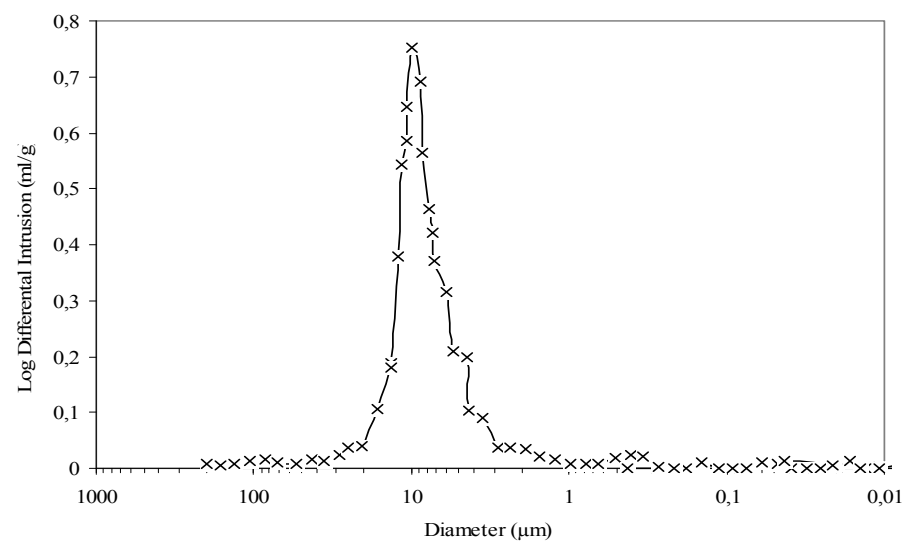

Fig. 5. Pore diameters of the silty marls supports. 
Sintering experiments of the support were carried out in air. Two steps has been realised: the first for the elimination of organic additives at $250^{\circ} \mathrm{C}$, and the second for the sintering at $1190^{\circ} \mathrm{C}$. The temperature-time schedule not only affects the pore diameters and porous volume of the final product but also determines the final morphology and mechanical strength. By controlling the sintering temperature of the ceramic, it is possible to increase the pore size and to obtain a higher mechanical strength. We have also observed that the obtained silty marls support presents the highest mean pore diameter for the highest mechanical strength: The support fired at $1190^{\circ} \mathrm{C}$ and characterised by mercury porosimetry showed mean pore diameters and porosity of about $9.2 \mu \mathrm{m}$ and $49 \%$ respectively (Fig.5).

\begin{tabular}{lccc}
\hline \multicolumn{1}{c}{ Powders } & Temperature $\left({ }^{\circ} \mathrm{C}\right)$ & Pore size $(\mu \mathrm{m})$ & Porous Volume $(\%)$ \\
\hline Crushed during one & 1160 & 9.6 & 58 \\
hour and calibrated & 1170 & 10.9 & 56 \\
with $125 \mu \mathrm{m}$ & 1180 & 12.8 & 53 \\
& 1190 & 14.3 & 52 \\
& 1200 & 16.5 & 51
\end{tabular}

$\begin{array}{llrl}\text { Crushed during two } & 1160 & 5.9 & 52 \\ \text { hours and calibrated } & 1170 & 7.3 & 50 \\ \text { with } 100 \mu \mathrm{m} & 1180 & 8.5 & 49 \\ & 1190 & 9.2 & 49 \\ & 1200 & 12.5 & 46\end{array}$

Table 2. Variation of pore size and porous volume according to the powder particle sizes for the silty marls (M11).

It can also be observed that the porosity and the pore size parameters are strongly dependent on the sintering temperature and particle size of the powders (Table 2).

2.2. Membrane shaping and characterisation:

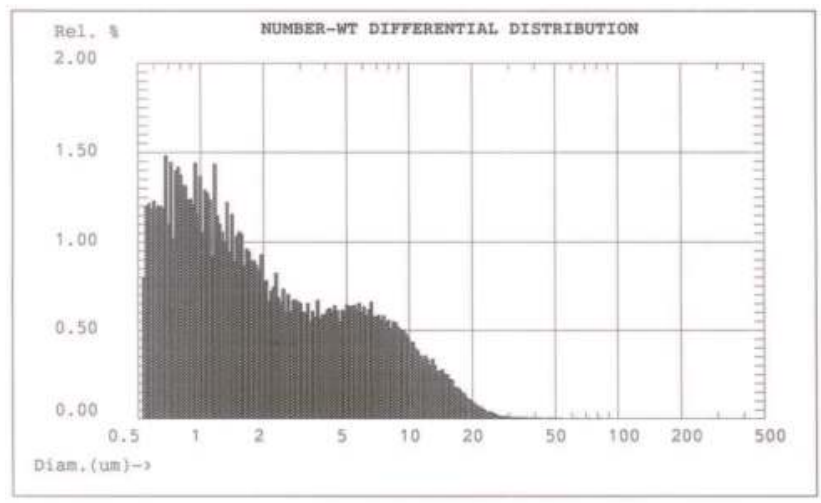

Fig. 6. Clay $\left(\mathrm{JM}_{18}\right)$ particle-size distribution. 
The material used for the membrane preparation is a Tunisian clay powder $\left(\mathrm{JM}_{18}\right)$ taken from the area of Sidi Bouzid (Central Tunisia). This powder is crushed for 4 hours with a planetary crusher at 250 revolution/min and calibrated with $50 \mu \mathrm{m}$. The obtained particle diameters range from about 0.5 to $23 \mu \mathrm{m}$. (Fig 6).

The chemical composition of the clay $\left(\mathrm{JM}_{18}\right)$ is shown in Table 3. It reveals that this material is essentially formed with a large amount of silica $62.64 \%$.

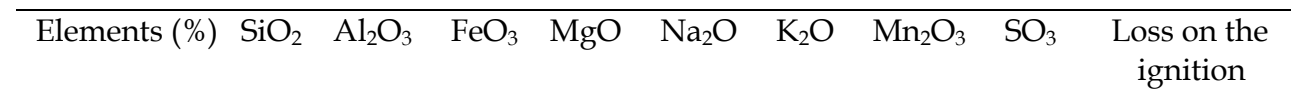

$\begin{array}{llllllllll}\mathrm{JM}_{18} & 62.64 & 17.09 & 8.5 & 0.07 & 0.32 & 4.8 & 0.02 & 0.4 & 6.16\end{array}$

Table 3. Composition of clay $\left(\mathrm{JM}_{18}\right)$.

For preparing a microfiltration layer with $\mathrm{JM}_{18}$, the suspended powder technique was used. A defloculated slip was obtained by mixing $5 \% \mathrm{w} / \mathrm{w}$ of $\mathrm{JM}_{18}, 30 \% \mathrm{w} / \mathrm{w}$ of Polyvinyl alcohol (PVA) $(12 \% \mathrm{w} / \mathrm{w}$ aqueous solution) as binder and water $(65 \% \mathrm{w} / \mathrm{w})$. The thickness of microfiltration layer can be controlled by the percentage of the clay powder added to the suspension and the deposition time.

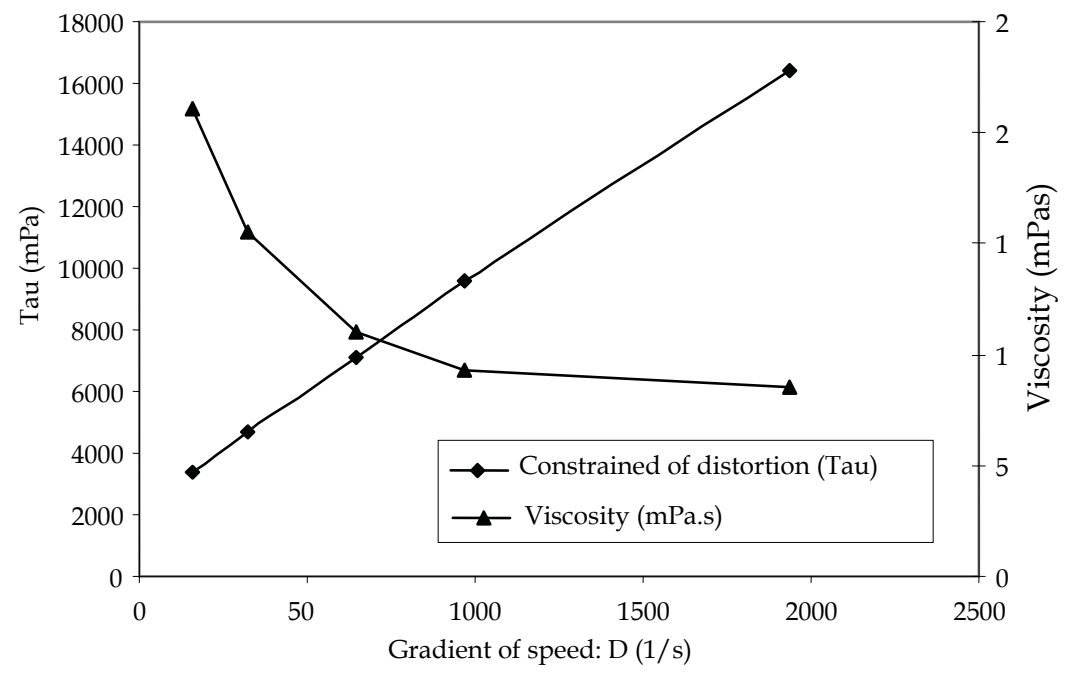

Fig. 7. Evolution of the stress $(\tau)$ and the viscosity ( $\mu$ ) vs. deformation of clay (JM 18) slip.

The viscosity of the slip elaborated according to the protocol described previously has been studied right before deposition. The used viscosimeter (LAMY, TVe-05) permits to use 5 speeds of rotation for the determination of the dynamic viscosity of the substance to characterize.

Figure 7 shows the rheogram of the slip used. It is done by the curve of schear stress $(\tau)$ versus speed of rotation (D). The slip has a plastic behaviour of Bingham, controlled by the 
presence of PVA; the value of the limiting shear stress is $4 \mathrm{mPa}$. Such behaviour permits the maintenance of particles in a stable suspension.

The deposition of the slip on the $\mathrm{M}_{11}$ support was performed by slip casting using a deposition time between 10 and $15 \mathrm{~min}$. After drying at room temperature for $24 \mathrm{~h}$. The clay membrane was sintered at $900^{\circ} \mathrm{C}$ for $2 \mathrm{~h}$, after debonding at $250^{\circ} \mathrm{C}$ for $1 \mathrm{~h}$.

Total porous volume and pore size distribution are measured by Mercury porosimetry. This technique relies on the penetration of mercury into a membrane's pores under pressure. The intrusion volume is recorded as a function of the applied pressure and then the pore size was determined. The pore diameters measured were centered near $0.18 \mu \mathrm{m}$ (Fig. 8).

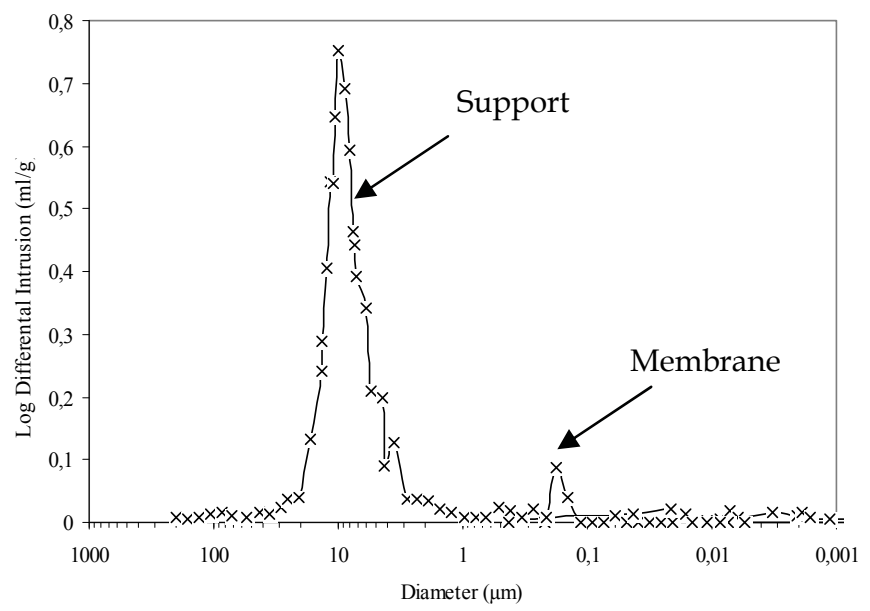

Fig. 8. Pore diameters of the clay $\left(\mathrm{JM}_{18}\right)$ membrane.

The pore size in the microfiltration layer can also be varied using powders with different particle size distributions.

Different microfiltration membranes with different layers thickness (between 5 and $50 \mu \mathrm{m}$ ) were prepared. SEM (scanning electron microscopy) images of the resulting membranes are shown in Figure 9. This figure gives information on the texture of the elaborated membrane surface. A defect free membrane was only obtained for membrane thickness less than $10 \mu \mathrm{m}$ (in order to $7 \mu \mathrm{m}$ ).
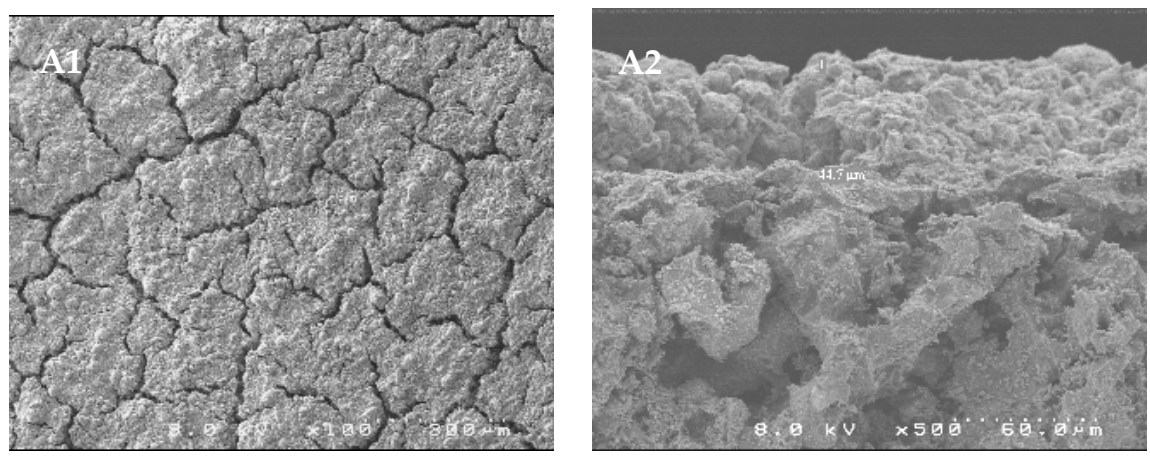

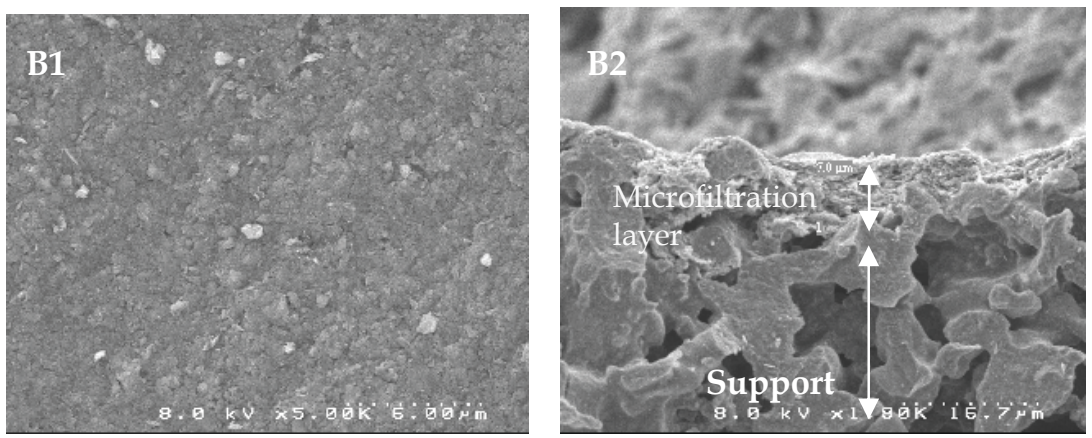

Fig. 9. Scanning electron micrographs of clay ( $\left.\mathrm{JM}_{18}\right)$ membrane: (A: Membrane thickness upper than $10 \mu \mathrm{m}, \mathrm{B}$ : Membrane thickness less than $10 \mu \mathrm{m}, 1$ : surface, 2: cross section)

Crossflow microfiltration tests were performed using a home-made pilot plant (Fig. 10) at a temperature of $25^{\circ} \mathrm{C}$ and transmembrane pressure (TMP) range between 1 and 4 bars.

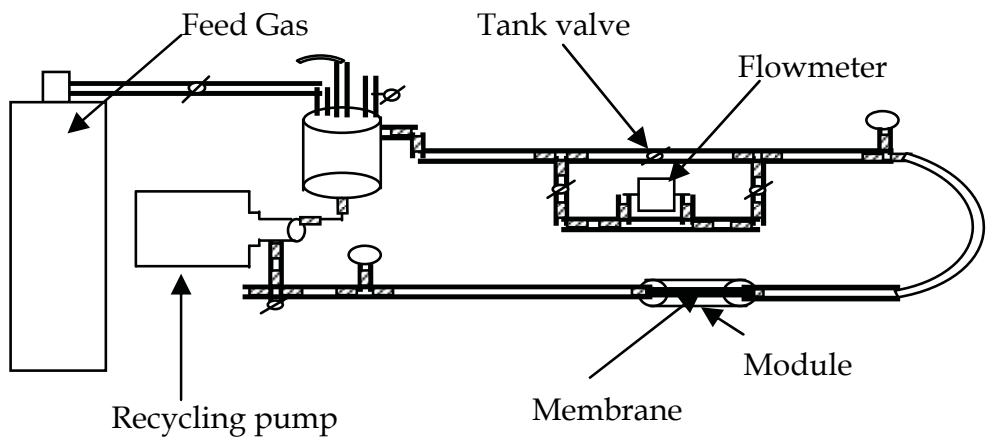

Fig. 10. Flow schema of experimental apparatus.

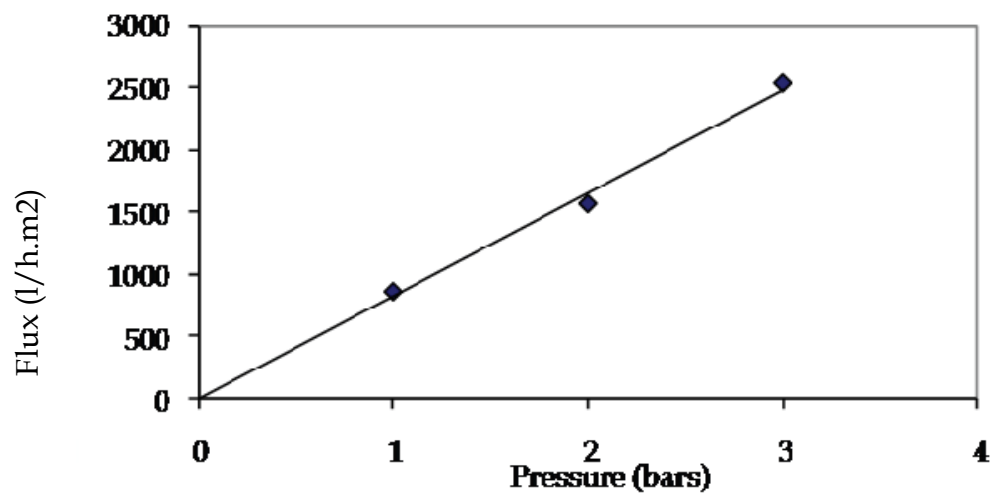

Fig. 11. Water fluxes vs. working pressure. 
The flow rate was fixed at $2.5 \mathrm{~m} \cdot \mathrm{s}^{-1}$. Before the tests, the membrane was conditioned by immersion in pure deionised water for a minimum of $24 \mathrm{~h}$. The working pressure was obtained using a nitrogen gas source. The membrane was initially characterized by the determination of water permeability which was $8701 . h^{-1} \cdot \mathrm{m}^{-2} \cdot$ bar $^{-1}$ (Fig. 11).

\subsection{Application for cuttlefish effluents treatment}

Membrane processes can be used for the treatment of wastewater produced by the sea products conditioning (Afonso et al., 2002). In our case, the prepared Microfiltration membranes have been applied to the cuttlefish effluent produced from cuttlefish conditioning and freezing process. The used samples were collected from a sea productfreezing factory located in Sfax (Tunisia). The dark colour in this type of effluent was due to the presence of particles in suspension (sepia ink) which has a size range between $56 \mathrm{~nm}$ and $161 \mathrm{~nm}$ (Flood et al., 1993).

Figure 12 gives the variation of permeate flux with transmembrane pressure which is done by: $\left(\mathrm{P}_{\text {inlet }}+\mathrm{P}_{\text {oulet }}\right) / 2$ - Pf where: $\mathrm{P}_{\text {inlet }}$ and are respectively the inlet and the outlet pressures across the filtration module.
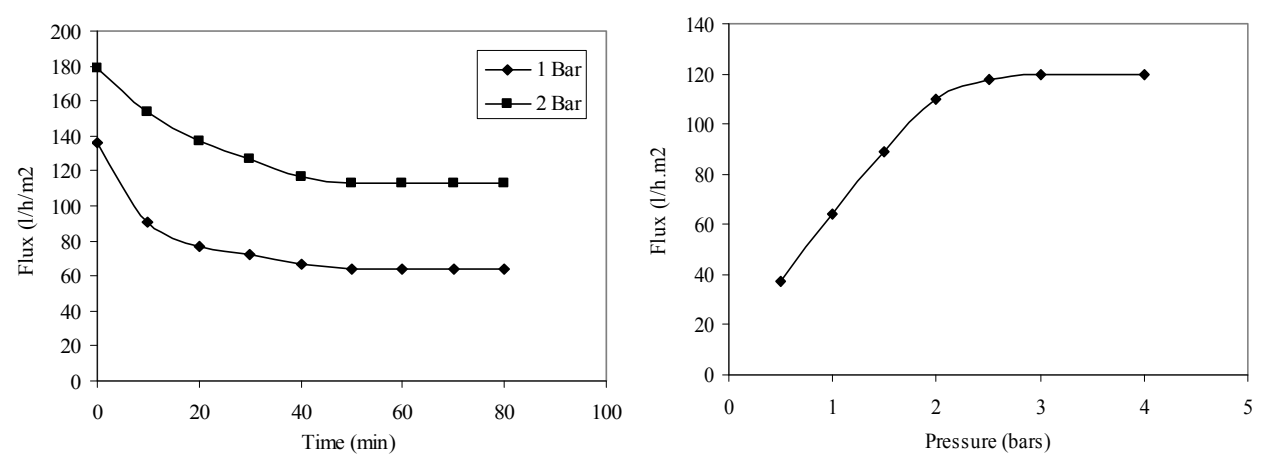

Fig. 12. Variation of flow according to the use pressure and time of filtration.

Permeate flux increased linearly with transmembrane pressure until a value of 2 bars and then stabilized at a value of $120 \mathrm{l} / \mathrm{h} . \mathrm{m}^{2}$. This behavior can be explained by the formation of a concentrated polarization layer. The variation of permeate flux with time shows that the fouling phenomenon is not very important: The permeate flux decreased by only $33 \%$.

Table 4 gives the main characteristics of the raw and treated effluent. It can be observed that the permeate turbidity determined by using a Turbidimeter (HACH RATIO 2100A); is very low (inferior to $1 \mathrm{NTU}$ ) and that the COD retention rate (COD is chemical organic demand determined by colorimetric method) is superior to $65 \%$.

These results confirm the efficiency of these microfiltration prepared membranes to cuttlefish effluent treatment.

In term of quality, figure 13 shows a noticeable elimination of suspended matter illustrated by the change of the effluent colour as well as the elimination of the turbidity. 


\begin{tabular}{cccc}
\hline Sample & Conductiviy $(\mathrm{mS} / \mathrm{cm})$ & Turbidity $(\mathrm{NTU})$ & DCO $(\mathrm{mg} / \mathrm{l})$ \\
\hline Raw effluent & 80 & $>2000$ & $6000-6500$ \\
Filtrate $(\mathrm{P}=1$ bar $)$ & 72 & 0,89 & 2460 \\
Filtrate $(\mathrm{P}=2$ bar $)$ & 70.5 & 0,62 & 1930 \\
\hline
\end{tabular}

Table 4. Characteristics of the effluent befor and after filtration.

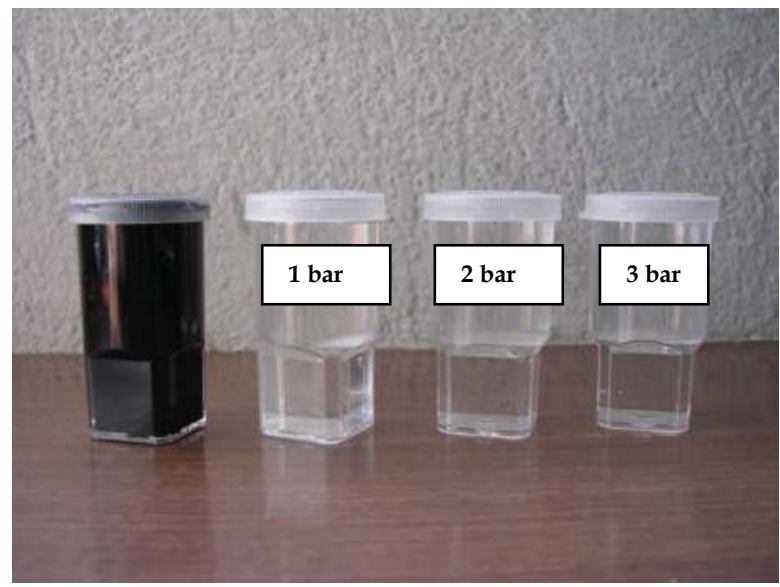

Fig. 13. A photograph of cuttlefish effluent before and after MF treatment.

\section{Conclusion}

In this work we have prepared new microfiltration membranes using natural powder derived from Tunisian natural material. The ceramic support was formed by the extrusion of a ceramic paste of silty marls $\left(\mathrm{M}_{11}\right)$. The microfiltration layer base on clay $\left(\mathrm{JM}_{18}\right)$, deposited onto the supports, was obtained by slip-casting method. An excellent link between the support and the microfiltration layer was obtained.

The support pore sizes could be carefully controlled by the choice of the particle diameters sizes of natural materials (silty marls). The desired pore sizes of the microfiltration layer $(<1 \mu \mathrm{m})$ were achieved by optimisation of the calcination temperatures. Microfiltration membranes from Tunisian clay with pore sizes as small as $0.18 \mu \mathrm{m}$ could be then produced. This membrane have a water permeability of $8701 . \mathrm{h}^{1} \cdot \mathrm{m}^{-2} \cdot \mathrm{bar}^{-1}$.

One application of these membranes is the washing cuttle-fish effluent treatment. These membranes can also be used as a support for ultrafiltration layer.

\section{References}

Cham, K. K. \& Brownstein, A. M. (1991). Ceramic membranes growth prospects and apportunities. Am. Ceram. Soc. Bull. Vol. 70, pp. 703-707. 
R. Uhlhorn, J. R.; Huis M. H.; Veld, J in ' t B.; Keizer, K.; \& Burggraaf, A. J. (1987). Science of ceramics, Vol. 14, pp. 551-556.

Zespalis,V. T.; Van Praag, W.; Keizer, K.; Van Ommen, J. G.; Ross, J. R. H. \& Burggraaf, A. J. (1989). Modified alumina membranes as active materials in catalytic processes, First Intern, ICIM, pp. 367-372, Montpellier, 3-6 July.

Cot, L. (1998). Inorganic membranes: academic exercise or industrial reality, inorganic membranes, Fifth Internal Conference on Inorganic Membranes, Nagoya, 22-26 June.

Jones,B. F. \& Galan, E. (1988). Sepiolite and palygorskite, in: S. W. Bailey (Ed.), Reviews in Mineralogy, Hydrous Phyllosilicates, Mineralogical Society of America, Washington Vol. 19, pp. 631-674.

Pérez, J.L. \& Rodriguez, E. Ga. (1994). Determination of impurity in sepiolite by thermal analysis, Thermal Anal, vol. 42, pp. 131-141.

Mishra, T. \& Parida, K. (1997). Transition-metal oxide pillared clays, part 2-A comparative study of textural and acidic properties of manganese(III) pillared montmorillonite and pillared acid-activited montmorillonite, J. Mater. Chem, Vol.7, No.(1), pp. 147152.

Cool, R.; Clearfiled, A.; Mariagnanam, Ellistrem, V.; L.J.Mc.; Crooks, R.M. \& Vansant, E.F. (1997). Self-assembly of aluminium-pillared clay on a gold support, J. Mater. Chem, Vol. 7, No. (3), pp. 443-448.

Messaoudi, L. ; Larbot, A. ; Rafiq, M. \& Cot, L. (1995). Mise au point d'une membrane de microfiltration sur supports tubulaires à base d'une argile marocaine, Ind. Ceram, Vol. 12, No. (910), pp. 831-835.

Ishiguro, M.; Matsuura, T. \& Detellier, C. (1995). Reverse osmosis separation for a montmorillonite membrane, j. Membr. Sci, Vol. 107, pp. 87-92.

Le Van Mao, R.; Rutinduka, E.; Detellier, C.; Gougay, P.; Hascoet, V.; Tavakoliyan, S.; Hoa, S.V. \& Matsura, T. (1999). Mechanical and pore characteristics of zeolite composite membrane, J. Mater. Chem, vol. 9, pp. 783-788.

Rakib, S.; Sghyar, M.; Rafiq, M. ; Larbot, A. \& Cot, L. (2000). Elaboration et caracterisation d'une ceramique marcroporeuse à base d'arène granitique, Ann. Chim. Sci. Mat, vol 25, pp. 567-576.

Dégrement, L. (1978). Mémento technique de l'eau, Paris, pp. 232-965.

Abdelmouleh, A. (1997). Etude expérimentale de la valorisation de l'allache et de la seiche en Tunisie, Thése de doctorat, p. 130-135.

Flood, R.; Deibel D. \& Morris, C. (1993). Oikopleura Vanhoeffeni Using Sepia Ink. Biol. Bull, vol. 178, p. 118-125.

Guizard, C.; Julbe, A.; Larbot A.; Cot, L.; Lee. in B.I. \& Pope (Eds.), E.J. (1994). Chemical Processing of Ceramics, Marcel Dekker Inc., New York, 501.

Khemakhem, S.; Ben Amar, R.; Larbot, A. Ben Salah, A. \& Cot, L. (2006). Fabrication of mineral supports of membranes for microfiltration/ultrafiltration from Tunisian clay, Ann. Chim. Sci. Mat., vol. 31, No. 2, pp. 169-181.

Afonso M.D., \& Borquez R., (2002). Review of the treatment of seafood processing wastewaters from the fish meal industry. Desalination, vol. 142, pp. 29-45. 


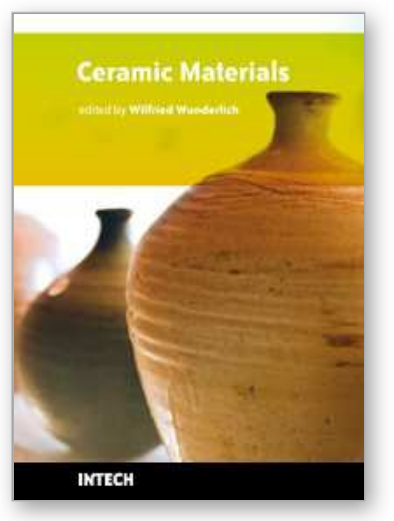

\author{
Ceramic Materials \\ Edited by Wilfried Wunderlich
}

ISBN 978-953-307-145-9

Hard cover, 228 pages

Publisher Sciyo

Published online 28, September, 2010

Published in print edition September, 2010

This is the first book of a series of forthcoming publications on this field by this publisher. The reader can enjoy both a classical printed version on demand for a small charge, as well as the online version free for download. Your citation decides about the acceptance, distribution, and impact of this piece of knowledge. Please enjoy reading and may this book help promote the progress in ceramic development for better life on earth.

\title{
How to reference
}

In order to correctly reference this scholarly work, feel free to copy and paste the following:

Sabeur Khemakhem, Andre Larbot and Raja Ben Amar (2010). New Ceramic Microfiltration Membranes from Tunisian Natural Materials: Application for the Cuttlefish Effluents Treatment, Ceramic Materials, Wilfried Wunderlich (Ed.), ISBN: 978-953-307-145-9, InTech, Available from:

http://www.intechopen.com/books/ceramic-materials/-new-ceramic-microfiltration-membranes-from-tunisiannatural-materials-application-for-the-cuttlefis

\section{INTECH}

open science | open minds

\author{
InTech Europe \\ University Campus STeP Ri \\ Slavka Krautzeka 83/A \\ 51000 Rijeka, Croatia \\ Phone: +385 (51) 770447 \\ Fax: +385 (51) 686166 \\ www.intechopen.com
}

\section{InTech China}

Unit 405, Office Block, Hotel Equatorial Shanghai

No.65, Yan An Road (West), Shanghai, 200040, China 中国上海市延安西路65号上海国际贵都大饭店办公楼 405 单元

Phone: +86-21-62489820

Fax: $+86-21-62489821$ 
(C) 2010 The Author(s). Licensee IntechOpen. This chapter is distributed under the terms of the Creative Commons Attribution-NonCommercialShareAlike-3.0 License, which permits use, distribution and reproduction for non-commercial purposes, provided the original is properly cited and derivative works building on this content are distributed under the same license. 